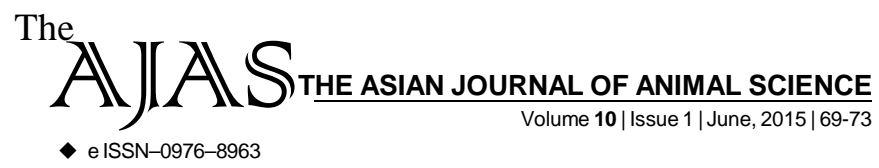

DOI : 10.15740/HAS/TAJAS/10.1/69-73 Visit us | www.researchjournal.co.in

RESEARCH ARTICLE.

\title{
Participation of rural women in animal husbandry development programmes and decision making regarding animals in Haryana
}

\begin{abstract}
ANIKA MALIK, GAUTAM AND KAMALDEEP
Author for Corresponding -

\section{ANIKA MALIK}

Department of Veterinary and

Animal Husbandry Extension

ABSTRACT...... Animal keeping is an integral part of rural life and is considered a pathway for women empowerment. Rural women play a key role in livestock management. However it is often argued that their contribution are undermined, underestimated and their decision making power are highly limited.The knowledge and skill of women dairy occupation and their participation in decision making certainly affects their efficiency in work and in the development of dairy enterprise. The study was conducted in Hisar district of Haryana state to assess the participation of women in decision making regarding animals and in animal husbandry development programmes. The respondents were selected using simple lottery method and 30 women farmers were chosen from each four selected villages thus constituting a sample size of 120. It was found that their participation in different areas varied. They can give only suggestions to their spouse in decision making regarding animals' purchase and sale, insurance, loans, participation in support programmes (like trainings) and not taking decisions independently. Only 1.67 per cent of women were found beneficiaries of training in last 5 years. None of the respondent women was a beneficiary of Composite Murrah Development Scheme and establishment of high value dairy units. And around 5 per cent women visit the hospital for treatment as compared to 95 per cent men and only 15 per cent women were beneficiaries of loan as compared to 85 per cent men. More attention should be given to rural women to build their capacities in decision making. Moreover appropriate ways and approaches should be adopted for providing equal access to women in Animal Husbandry Development Programmes.
\end{abstract}

Education, College of Veterinary

Sciences, Lala Lajpat Rai

University of Veterinary and

Animal Sciences, HISAR

(HARYANA) INDIA

Email: anikadhundwal@gmail.com

See end of the article for

Coopted authors'
KEY WORDS...... Rural women, Decision making, Animal husbandry, Development programmes

HOW TO CITE THIS ARTICLE - Malik, Anika, Gautam and Kamaldeep (2015). Participation of rural women in animal husbandry development programmes and decision making regarding animals in Haryana. Asian J. Animal Sci., 10(1) : 69-73.

ARTICLE CHRONICLE - Received : 01.05.2015; Revised : 29.05.2015; Accepted : 30.05.2015 